\title{
Agata Wołowska, „Przywiązanie do organizacji a kontrakt psychologiczny", Wydawnictwo Naukowe Uniwersytetu Mikołaja Kopernika, Toruń 2013
}

Od ponad 30 lat organizacje pozostają pod wpływem gwałtownie dokonujących się zmian na rynku pracy, co wymusza na nich radykalną rewizję strategii zatrudnienia. Poszukując kreatywnych i innowacyjnych sposobów podniesienia poziomu efektywności, obniżenia kosztów i usprawnienia procesów wewnątrzorganizacyjnych ograniczają stałe zatrudnienie, gdyż w tym widzą podstawowe źródło osiągania i utrzymania rynkowej konkurencyjności. Poza redukcją zatrudnienia, firmy stosują również inne niż tradycyjne formy nawiązywania stosunku pracy, których charakterystyczną cechą jest elastyczność. Wprowadzanie niestandardowych form zatrudnienia, jak np. umowy krótkoterminowe, ma na celu głównie obniżenie kosztów stałych przedsiębiorstwa. Stosowanie zatrudnienia czasowego jest uznawane za szansę na zwiększenie zdolności firmy do przystosowania siły roboczej, do zmian zapotrzebowania na współczesnym rynku.

Publikacja Agaty Wołowskiej pt. „Przywiązanie do organizacji a kontrakt psychologiczny" podejmuje problem konsekwencji zmian dokonujących się obecnie na rynku pracy oraz wewnątrz organizacji dla jednej z najczęściej opisywanych w literaturze przedmiotu postawy związanej z pracą, tj. przywiązania do organizacji. Zmiany, uwzględnione w książce, opisane zostały w postaci trzech głównych wątków. Pierwszy z nich dotyczy wzrostu liczby firm/organizacji prywatnych na polskim rynku pracy, w stosunku do państwowego sektora gospodarki. Drugi wątek odnosi się do sposobu zatrudniania pracowników, w którym obserwuje się wyraźny wzrost zatrudnienia czasowego w stosunku do umów stałych o pracę. Trzecim ważnym aspektem związanym $\mathrm{z}$ relacją pracownik-organizacja jest naruszenie 
kontraktu psychologicznego, które rozpatrywane w kategoriach wymiany jest niezwykle trafnym konstruktem, umożliwiającym wyjaśnienie zachowań pracowników w dynamicznych warunkach działania współczesnych organizacji.

Książka składa się z dwóch części. Część teoretyczną, poświęconą charakterystyce głównych pojęć, konstytuują trzy rozdziały. Pierwszy z nich odnosi się do pojęcia przywiązania do organizacji i zawiera omówienie jego ewolucji, zarówno w paradygmacie etologicznym, jak i fenomenologicznym, a także przegląd jego różnych koncepcji z ukazaniem łączących ich podobieństw i dzielących różnic. Rozdział zamyka przedstawienie kluczowego dla książki trójwymiarowego modelu Meyera i Allen (1997). Przywiązanie do organizacji zdefiniowane zostało jako siła wiążąca jednostkę z kierunkiem działania, która doświadczana jest jako stan umysłu, mogący przyjąć różne formy: pragnienia pozostania w organizacji, spostrzeganego kosztu związanego z jej opuszczeniem lub poczucia moralnego obowiązku do kontynuowania kierunku działania. Te stany umysłu odzwierciedlają trzy wyróżnione przez badaczy komponenty leżące u podstaw pojęcia przywiązania: afektywny, trwałości i normatywny, do których Autorka podaje bogate odniesienia empiryczne dotyczące badania determinant, korelatów i konsekwencji przywiązania do organizacji.

Rozdział drugi części teoretycznej został poświęcony kontraktowi psychologicznemu, który według definicji Rousseau (1995), przyjętej przez Autorkę książki, jest zespołem przekonań ludzi, odnośnie do umowy dotyczącej warunków wymiany i wynikających z nich korzyści zarówno dla pracodawcy, jak i pracobiorcy. Warunki, w jakich muszą działać współczesne organizacje prowadzące do zmian w relacji zatrudnienia zwiększają prawdopodobieństwo, że ów kontrakt psychologiczny zostanie naruszony, gdyż każda zmiana zewnętrzna wpływa na zmianę percepcji kontraktu psychologicznego. Opis konsekwencji naruszenia kontraktu psychologicznego, a także charakterystykę współczesnej rzeczywistości organizacyjnej i elastycznego zatrudnienia jako efektywnego sposobu adaptacji do współczesnego rynku zawarto $\mathrm{w}$ rozdziale trzecim.

W części empirycznej Autorka przyjęła założenie o istotnym wpływie naruszenia kontraktu psychologicznego na budowanie przez pracownika jego więzi z organizacją. Mechanizm, za pośrednictwem, którego kontrakt psychologiczny wpływa na przywiązanie pracownika do organizacji, został wyjaśniony na gruncie teorii wymiany społecznej, zgodnie z którą jednostka świadcząca usługi na rzecz drugiej strony, zobowiązuje ją do odwzajemnienia się. Druga strona, aby spłacić powstałe zobowiązanie, winna dostar- 
czyć korzyści tej pierwszej. Jeżeli jedna ze stron nie zrewanżuje się drugiej, zakłóca to równowagę między stronami odnośnie ich wkładu, co w konsekwencji przyczynia się do kształtowania bardziej negatywnych postaw wobec pracy, np. osłabienia więzi łączącej pracownika z organizacją.

Innym celem badania opisywanym $\mathrm{w}$ książce było przedstawienie związków polityki elastycznego zatrudnienia z przywiązaniem do organizacji, jak również ustalenie, jakie czynniki środowiska organizacyjnego, cechy dyspozycyjne oraz indywidualne czynniki kontekstu pracy sprzyjają wzrostowi przywiązania do organizacji.

Uszczegółowiając, w części empirycznej książki, Autorka stawia trzy złożone problemy badawcze. Pierwszy z nich dotyczy związku przywiązania organizacyjnego $\mathrm{z}$ rodzajem zatrudnienia (czasowe vs stałe) oraz formą własności organizacji (prywatna vs państwowa). Jest to więc pytanie o to, czy rodzaj zatrudnienia i forma własności różnicują opisywaną postawę. Drugi problem to pytanie o predyktory przywiązania organizacyjnego. Autorka poszukuje ich wśród indywidualnych czynników kontekstu pracy (tj. wiek, płeć, rodzaj umowy o pracę, staż pracy w firmie), zmiennych dyspozycyjnych (tj. samoocena, poczucie umiejscowienia kontroli pracy), naruszenia kontraktu psychologicznego oraz wymiarów klimatu psychologicznego (tj. bezpieczeństwo psychiczne i znaczenie pracy). Formułując trzeci problem Autorka uwzględniła wyniki dotyczące problemu drugiego, które ujawniły istotne znaczenie klimatu psychologicznego dla przywiązania organizacyjnego. Problem trzeci odnosi się więc, do pytania o to, czy wymiary klimatu psychologicznego zapośredniczają relację między naruszeniem kontraktu psychologicznego a przywiązaniem do organizacji. Adekwatnie do problemów badawczych sformułowano 9 hipotez szczegółowych. Każda z hipotez uzasadniona została poprzez odwołanie się do analizy teoretycznej, bądź do przeprowadzonych dotychczas na temat rozpatrywanego związku badań, co stanowi dużą zaletę opisanego w książce planu badawczego.

Badanie przeprowadzono na 330 osobowej grupie kobiet i mężczyzn. Byli to pracownicy firm państwowych (N=205) i prywatnych (N=125) o zróżnicowanym typie umowy o pracę - umowy długoterminowe oraz umowy na czas określony. Wykorzystano w nim starannie dobrane i szczegółowo omówione narzędzia o satysfakcjonujących właściwościach psychometrycznych. Część z nich została przetłumaczona z języka angielskiego z zachowaniem procedur służących adaptacji obcojęzycznych narzędzi, a jedno specjalnie na użytek prowadzonego badania zostało skonstruowane przez Autorkę.

Hipotezy weryfikowano w oparciu o analizę wariancji, hierarchiczną analizę regresji oraz analizę mediacji, których wyniki zostały przejrzyście 
przedstawione w postaci tabel i rycin. Wyniki analiz ujawniły, że naruszenie kontraktu psychologicznego i klimat psychologiczny są istotnymi wyznacznikami przywiązania do organizacji, a ponadto, że wymiary klimatu psychologicznego mediują zależność między naruszeniem kontraktu psychologicznego i przywiązaniem do organizacji, z tą różnicą, że w firmie państwowej mediatorem okazało się znaczenie pracy, natomiast w firmie prywatnej bezpieczeństwo psychiczne.

Przedstawiona publikacja jest godna polecenia czytelnikowi z kilku powodów. Nie istnieje w polskiej literaturze psychologicznej tak obszerne opracowanie na temat przywiązania do organizacji. Niektóre fragmenty części teoretycznej mają walor dydaktyczny i mogłyby być wykorzystane jako podręcznik dla studentów. Ponadto niewątpliwym plusem tej ciekawej - tak w sensie poznawczym, jak i aplikacyjnym - książki jest pogłębiona dyskusja wyników, której wnioski mogą być wykorzystane w praktyce zarządzania przedsiębiorstwem.

Lidia A. Wiśniewska 